\title{
Research on ideological and political education methods in colleges and universities based on new media
}

\author{
Hui Gao ${ }^{1}$ \\ ${ }^{1}$ Vocational and Technical College Dezhou, Dezhou, China Huigao
}

\begin{abstract}
Nowadays, the upgrading of mobile internet equipment has given a broad space for improvement on media technology, new media has quickly integrated into social production and life. College education is facing new changes in information dissemination. Through a detailed description of the characteristics of new media information dissemination, this article points out the current opportunities for the development of ideological and political education in its environment in my country. It explores new teaching methods from four perspectives: teaching concepts, teaching mechanisms, teaching resources, and teaching methods. It is vital to enhance the improvement on teaching effects.
\end{abstract}

\section{Introduction}

Since the beginning of the 21 st century, the maturity and popularization of mobile Internet technologies and applications represented by mobile smartphones and mobile communication technologies have brought new vitality to traditional industries under the transformation and upgrading of "Internet + " thinking and innovation. And vitality. The emergence of $\mathrm{c}$ is a breakthrough in traditional media based on the characteristics of high efficiency, fast speed, large coverage, and interconnection of network information [1,2].

As a critical factor in moral lessons, ideological and political education turns into a method of modern ideological and political education that aims at establishing morality and fostering people, and shaping the comprehensive development of college students with both moral integrity and ability, character and academic excellence. In traditional ideological and political classroom teaching, college students have poor learning initiative and weak participation, and cannot effectively absorb and integrate ideological and political theoretical knowledge points, and cannot guide themselves in learning and living.

The teaching work with the help of new media communication platforms, communication technologies, and communication methods has been implemented in most colleges and universities [3, 4]. It has received good feedback from teachers and students and achieved good teaching results. However, the new media ideological and political teaching under the guidance of "Internet +" education has been in a state of groping, and online education theories have not yet becomed a whole system. How can new media be used as teaching tools and means to maximize thinking? There is still room for further improvement on the part in political education. Therefore, ideological and political education should open up new paths and create new methods under the new media environment.

The upgrading of mobile internet devices has given wide room for development on new media technologies. At present, new media technologies for example Weibo, WeChat, and cloud space have normally made dominant carriers of student learning and entertainment, and have become an indispensable part of student life. In the environment, the change of learners' learning styles brings greater development chances of ideological and political education. Besides, it brings opportunities for the modernization of teaching. In this context, it is important to explore new teaching ways in response to the various caused by new media on the teaching of ideological and political courses to enhance significant changes of learning effects.

\section{New media concept explanation}

New media is also called digital communication media. Its concept is a new Internet concept created by American communication expert Goldmark with new performance and influence on computer information communication. The nature of new media belongs to a category on media, which is named because its dissemination nature is completely different from formal media such as newspapers, TV, radio, and magazines. The information dissemination technology of new media is the cooperation of digital technology and network technology. Then computers, mobile phones, and mobile smart terminals in each user's hands are not only the terminals of communication but also the media of communication. It has the following attributes, namely, the sensitivity of information generation, which allows information to be quickly spread among users; the progress on information dissemination, which allows information to be instantly 
synchronized and collected by users without being restricted by time and space; the equality of information interaction and Freedom, allowing users to fully publish comments under legal regulations.

New media is an innovative application of science and technology in information dissemination. Among them, universities are the main dissemination group of new media, and their participation and activity in new media information participation are much higher than other groups. Due to the free and open cyberspace of new media, it is filled with a variety of ideological consciousness and spiritual connotations, coupled with the imperfect legal supervision of virtual online platforms, making new media platforms full of socialist core values positive energy. Contemporary college students are in the critical period of forming the Three Views, and they are easily influenced by the information under the gorgeous packaging in the complex new media environment. To this end, the institutions will use new media to create ideological and ethical concepts that are compatible with the mainstream socialist value system for undergraduates, to achieve transformation and upgrading of ideological and political education.

\section{3 beneficial new media environment of ideological and political courses}

\subsection{Enrichment and initiative of teaching methods}

Nowadays, the formal ideological and political teaching mode limited the thinking of teachers and students to designated teaching places and conducted face-to-face exchanges and discussions on teaching content. The advent of the new media era and its application in it can realize remote and online teaching of these courses and provide more diversified methods for teaching. For students, the learning of ideological and political courses in the new media environment is freer and the resources available for selection are more abundant. For teachers, on the online platform, teachers can conduct video teaching with students, and realize real-time dialogue with students in social software, to gain a more comprehensive realization of the real situation of students' learning and complete the point-to-point push of teaching content. Besides, they assisted by new media can also establish an online and offline auxiliary teaching model. Their spare time could be utilized to complete auxiliary learning, creating more space for their classrooms, alleviating teachers' pressure on teaching, and being more conducive to them. The transmission of the key points of the lesson knowledge enables students to complete the understanding of ideological and political knowledge at a deeper level with the cooperation of online and offline learning, and realize the independent and efficient development of ideological and political learning.

\subsection{Teaching methods are more flexible}

The fast improvement on network technology have enriched several channels for contemporary undergraduates to obtain information, and meanwhile promoting the progress on learners' personalities more closed. Some students are unwilling to take the initiative to communicate with teachers and get the assistance on ideological and political teachers when encounters problems encountered in their development. Given this situation, it is difficult for traditional classrooms to achieve effective cooperation and communication, and breaking through the identity restrictions and communication barriers among groups, resulting in reduced flexibility on education of these courses, and ultimately resulting teaching the effect is not ideal. The application of new media technology can create a virtual space on the Internet. Students can communicate with teachers or education experts anonymously to solve the communication difficulties of these students and enable students to express themselves more freely and truthfully. Their work is relatively relaxed and natural. Besides, on the online platform, teachers can place the knowledge content that cannot be expanded in the classroom outside of class, use social software to complete the push of current affairs news and hot spots, pass more authoritative content to students, and optimize the knowledge structure of students. The moral education methods in universities is more free and flexible.

\section{Challenges and opportunities}

\subsection{Weakening the authority of ideological and political teachers' discourse}

The main change brought about by new media technology to moral education in colleges and universities in the establishment of online learning platforms. The acquisition of moral knowledge in cyberspace is highly efficient. At the same time, the virtual nature of cyberspace is critical for its education. The authority of the workers' discourse brings challenges. In traditional ideological and political classrooms, the channels for students to acquire knowledge mainly depend on teachers' explanations of knowledge. The richness of teachers' knowledge and the authority of discourse can build bright figures in the hearts of students. And make teachers become the leaders and speakers, and ensure orderly and effective moral education through ideological guidance and behavior norms for students. The application on new media in ideological and political teaching has changed the status of teachers and the authority of discourse. New media technology has brought more abundant knowledge acquisition channels for students, and the content pushed to students will also be changed according to students' preferences. For students, this way of learning is more arbitrary, making students less dependent on traditional classrooms, and teachers' dominant position in teaching has also been impacted. Meanwhile, due to the majority of network information and data, students can freely obtain knowledge in the network space, which is prone to 
blindness and waste of study time, which brings greater difficulty to school moral education.

\subsection{Increase the dependence on new media}

The advanced nature of new media technology has brought convenience to ideological and political teaching, and research activities carried out by teachers with the aid of new media are more effective, and they can gain more rest time for teachers. In this environment, teachers are prone to over-reliance on new media and neglect to understand the real environment of postgraduates' learning, leading to stagnant abilities and education levels of teachers, making it difficult to achieve breakthroughs in teaching. Influenced by the teaching methods of teachers, students will also form the habit of learning under the unfamiliar situation. The knowledge acquisition in the new media space is more convenient and the content learned is also richer. Especially the emergence of social software makes communication between students more convenient. Some students who lack self-control and discrimination will use their spare time to $\log$ on to the Internet for online chat, and even some students will use their mobile phones to browse the station during class, which affects their learning effects in class.

\subsection{Bad network information causes and wrong public opinion orientation}

The overly complex environment of cyberspace affects students' ideology. Under the effect of the virtual nature of the Internet, most Internet users will publish wrong speeches to obtain sufficient attention and clicks, and create a public opinion orientation in cyberspace. Even some criminals will use the Internet to spread harmful information and harm the vital interests of citizens. As the most active group in the network environment, college students lack certain social and life experience and are vulnerable to the influence of bad information, causing deviations in the development of students' ideas and ideologies, and adversely influencing improvement on learners among all aspects, it adds difficulty to moral education and teaching in institution. Meanwhile, online social software or games will offer students with broad display environment. Furthermore, students who are in a period of publicity, they will use the Internet to express their opinions. After gaining recognition, students will have a sense of dependence on the Internet.

\section{Optimization of the teaching methods}

The new media technology has its own merits and demerits for a college education. If it is cited properly, it could earn twice the result with half the effort, and if it is cited incorrectly, it will be counterproductive. New media has a huge amount of information dissemination, fast speed, wide-coverage, low controllability, and there are blind spots in legal supervision, resulting in dissemination of good and bad content, and some of the content is likely to harm young college students, which brings moral education to colleges and universities. Brings serious challenges. How to make use of the advantages of the new media platform, overcome the current challenges, and let the moral education glow with vitality and vitality, has become one of the important research topics in the current college moral theory teaching. Based on many years of ideological and political teaching experience in colleges and universities, and through a comprehensive and indepth understanding of the feasibility conditions and obstacles of the combination of these technology, the following teaching innovation paths are proposed to handle this issue. Therefore the brief structure of the proposed teaching method could be given as Figure 1.

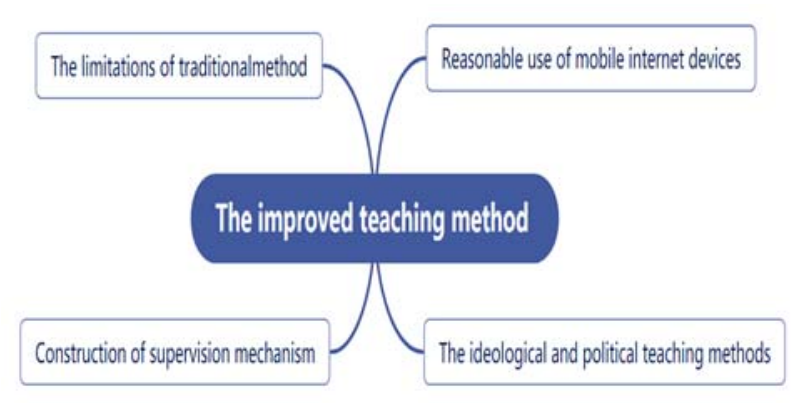

Fig 1. the structure of the improved teaching method

\section{1 the limitations of traditional thinking and establish a teaching philosophy that makes full use of new media}

For nowadays' educational environment, if university moral educators want to realize the application of new media technology and give full play to its full educational value, they must actively change their teaching concepts and eliminate the traditional teaching model that does not conform to the status quo of students' perception The factors that create a free and equal educational philosophy, and master more educational skills. Only in this way can we show the authority of teachers in and out of class and become a modern ideological and political education worker who can keep up with the rhythm. According to the current situation of the construction of ideological and political teachers in colleges and universities, they are mainly divided into two types. One is old teachers with rich teaching experience. They have a high academic research level, but there are also shortcomings in the application of new media technology. . The second is young teachers who are full of vitality. They have a strong ability to accept new things and apply new knowledge and ideas widely, but they lack experience in handling unexpected problems in teaching practice. Given the problems of teachers, colleges and universities should recognize the educational value of new media technology, and clarify the urgency of reforming ideological and political education concepts. Teachers can be stratified according to their teaching experience in a specific practice. Experienced teachers can be trained in new media technology-related skills and strengthen practical exercises on operations, so those old teachers can gradually master the operating process of new media technology. And complete the application in the classroom. For young teachers with less experience, colleges and 
universities can carry out teaching and research theme projects to gain more diverse new media teaching experience through the assistance of teachers. After completing the stratified training activities, colleges and universities should also organize teachers of different levels to cooperate in teaching, and complete the transmission of teaching concepts and methods in the cooperation.

\subsection{Reasonable use of mobile internet devices}

The institutions can use the Internet and mobile phone devices to carry out various educational activities and realize the innovation of ideological and political education carriers. In the online teaching space, ideological and political teachers can first use the campus forum as a database of teaching information to deeply explore the advantages of students' thoughts, and rationally select the educational information in the campus forum to complete student learning assistance. As a network facility established earlier, campus forums have a certain lag in comparison with modern social software. For the content that cannot be delivered in campus forums, teachers can use Weibo, cloud space, and other devices to establish public accounts, and establish interactive topics for key ideological and political information, guide students to participate in topic discussions, and understand the opinions and opinions expressed by students The state of the student's ideological development. On the mobile phone platform, teachers can use the WeChat group chat function to send text and voice messages, guide students to discuss topics, and record the content of students' speeches on the platform to provide teachers with data for subsequent teaching research. Besides, teachers can also establish friendships with students, pay attention to the dynamics posted by students on WeChat, understand the changes in students' thinking, and provide students with solutions to promote the sound development of students' thoughts and ideologies.

\subsection{Constructing and improving supervision mechanism to provide support for ideological and political education}

Under the influence of the multiculturalism of the new media environment, the changes in students' thoughts present a trend of diversified development. To effectively identify the dynamic changes and problems of students' thoughts, universities must establish a sound supervision mechanism to provide support for the practical application of innovative educational methods.

Firstly, universities could form a management structure that fits the reality of environment. Colleges and universities should play their guiding role, encourage staff from various departments of them to participate in teaching management, and through collaboration and communication between the staff of various departments, gather more forces to solve ideological and political education problems and promote ideological and political education to new media.
Secondly, universities should establish a complete monitoring mechanism for the use of new media. Full-time personnel can be arranged to filter the information in the new media platform, and then push it to students after completing the information screening, to reduce the influence of bad information on the students' thoughts and ideologies. Access standards should also be set up in the platform, and students can only enter the platform after completing the real-name registration to complete online learning and discussions. The establishment of this standard can not only restrict students' speech, but also effectively record the trajectory of students' online learning, and provide help for better completion of teaching data analysis and research.

\subsection{Colleges and universities should do a good job in improving the ideological and political teaching methods under the new media platform}

First of all, it is necessary to focus on combining the theory of ideological and political education with the reality of students' lives through new media, to truly change the status quo that ideological and political education mainly relies on classroom teaching, and make new media a powerful supplement that can achieve better teaching results; secondly, it can The combination of new media and traditional classroom teaching is used to achieve the transformation and upgrading of a current college education. For example, new media technology can be used to assist ideological and political teachers to enrich classroom teaching methods, improve classroom teaching efficiency, and do a good job in classroom effect evaluation; Third, ideological and political teachers can selectively use language in the new media environment based on the principle of "take the essence and eliminate the dross", critically absorb the way of thinking, and apply it to the ideological and political teaching content, so that the traditional classroom teaching becomes more vivid and appealing, giving new students vitality, and effectively driving students to integrate into the teaching system.

\section{Conclusion and future work}

All in all, strengthening the application of new media technology in a new educational environment is an inevitable choice for the modernization of ideological and political education in colleges and universities. In the new media platform, colleges and universities should not only strengthen the renewal of educational concepts, but also explore diversified educational methods, and provide students with multi-channel teaching services, to realize the practical improvement of the overall teaching effectiveness of ideological and political courses, and complete the ideological and political education of universities. Only in this way can ideological and political education play a good guiding role for contemporary college students and promote them to become high-quality talents with both ability and political integrity. 


\section{References}

1. Wei, Yunxia. "Reflection on College Education and Teaching Management under New Media." (2020).

2. Zhang, Jun $\mathrm{Li}$, and $\mathrm{Y}$. J. Sun. "Innovative Psychological Education of College Students Based on New Media." (2017).

3. Xiao-Xue, Wang. "On the Approaches to College Counselors' Network Ideological and Political Education in New Media Era." Journal of Lianyungang Technical College (2017).

4. Zhang, Liping. "Analysis on Penetrative Effects of New Media on Ideological and Political Education of Universities and Colleges." Open Journal of Social Sciences 03.12(2015):207-211. 